\title{
Collaborative Reasoning Technique in Developing Moral Comprehension
}

\author{
Lenny Wahyuningsih ${ }^{1}$, M. Solehuddin, Tina Hayati Dahlan \\ Universitas Pendidikan Indonesia, Indonesia \\ @lennybulense@gmail.com ${ }^{1}$
}

\section{Article Information:}

Received August 4, 2018

Revised August 30, 2018

Accepted December 25, 2018

Keywords: collaborative reasoning; moral

comprehension; students

\begin{abstract}
This study aims to find out about the collaborative reasoning technique to develop students' Moral Comprehension in tenth grade of State High School 1 Gegesik. The research approach used was the quasi-experimental method and non-equivalent control group research design. Research instruments using the Defining Issue Test (Rest's DIT-1). The results of the research are: (1) the Moral Comprehension of students is generally in stage 4; (2) the results of the dissemination of DIT-1 instruments; and (3) guidance and counseling programs with collaborative reasoning proven effective in developing students' Moral Comprehension with changes in the stages of Moral Comprehension of students. Success criteria due to more than $50 \%$ of students are in steps 4,5 and 6 .
\end{abstract}

\section{INTRODUCTION}

Individual moral development is critical, especially in adolescence. The moral aspect is an essential requirement for adolescents, especially as a unique guide to find their identity, develop a harmonious personal relationship and avoid role conflicts that always occur in the transition period (Desmita, 2009). Adolescence is an essential period in moral development, especially when adolescents (students) move from relatively similar primary schools to more various secondary schools and campus environments (Santrock, 2014). At this age, students are faced with contradictions between moral concepts that have been received and what has been experienced outside the family environment. As disclosed Kauffman moral comprehension is understood as a person's ability to judge an action from goodness, ugliness, truth, and error and decide what should be done based on the assessment (Mujahidah, 2009).

Moral problems cannot be separated from human life. The rapid improvement of science and technology has a positive and negative impact on both sides for adolescents. The adverse effects of the development of mass media and technology today are not only happening among adolescents but also children in primary school age. Case after case happened to the young generation. The results of a survey by one of the National Institutions for Child Protection and the National Narcotics Agency showed that $63 \%$ of middle school and high school students in Indonesia had premarital sex and $22 \%$ of narcotics users in Indonesia were from students and college students (Mulyani et al., 2017). The above phenomenon is reinforced by the results of a survey of the Indonesian Child Protection Commission in 33 provinces of Indonesia during January to September 2010 revealed that $62.7 \%$ of teenagers claimed to had a sexual relationship (Mariani \& Bachtiar, 2011). Other results from the Indonesian Women's Protection commission survey (Ma'mun, 2012), showed that $93.7 \%$ of junior and senior high school students had kissed, $21.2 \%$ of junior high school students had admitted doing abortion, and $97 \%$ of junior and senior high school students had

$\begin{array}{ll}\text { How to cite: } & \text { Wahyuningsih, L., Solehuddin, M., \& Dahlan, T. H. (2019). Collaborative Reasoning Technique in } \\ & \text { Developing Moral Comprehension. Islamic Guidance and Counseling Journal, 2(1). 18-25. } \\ & \text { https://doi.org/10.25217/igcj.v2i1.301 } \\ \text { E-ISSN: } & \text { 2614-1566 } \\ \text { Published by: } & \text { Institut Agama Islam Ma'arif NU (IAIMNU) Metro Lampung } \\ \text { Available online: } & \text { https://journal.iaimnumetrolampung.ac.id/index.php/igcj }\end{array}$


seen pornographic films. The Ministry of health of Indonesia showed that 673 cases of AIDS, and 10,376 cases of HIV positive were most prevalent in the productive age group 25-49 years $(69.6 \%)$, followed by the age group $20-24$ years $(17.6 \%)$, and the age group $\geq 50$ years (6.7\%) (Indonesia \& Pencegahan, 2017).

The phenomenon of misguided behavior towards moral values among students is not a new problem, and various things can cause it. However, Kohlberg argues that although many factors can lead to delinquency, high levels of moral comprehension function at least as a barrier to delinquency behaviour (Duska \& Whelan, 1975). The people who have higher moral comprehension, will be less involved in anti-social actions, cheating, and less behave following pressure from others (Rest, 1973).

Through active interaction students are more motivated, confident, able to use highlevel thinking strategies, and build interpersonal relationships. The approach of collaborative reasoning allows students to engage in social interaction between individuals in groups to build understanding or knowledge of each group member and encourage dialogical thinking, reasoned arguments, and different perspectives on controversial issues (Bonk \& Dennen, 2007). The focus of interaction is exploring the complexity of the problem from many perspectives (Young, 2014).

The collaborative reasoning $(\mathrm{CR})$ paradigm, like the peer instruction approach, is intended to enhance cooperative learning from peers, and thus engage and stimulate students to improve. CR has proved effectively provides a forum for extended meaningful communication and promotes language development and thinking skills of all students (Zhang \& Stahl, 2011). Teaching the principles of reasoning in computing, there are several places of interest for couples or groups of students to collaborate, and to give and receive feedback (Drchova, Hallstrom, Hollingsworth, Krone, \& Sitaraman, 2013).

Several previous study were found that collaborative reasoning is an effective method to promoting the development of individual argumentation (Reznitskaya et al., 2009), this research emphasized the importance of freely communication without being nominated by teacher. The interaction among students established naturally, authority is shared and no role given by the teacher. Another study state that $\mathrm{CR}$ is an appropriate method to improve student reading and thinking skills (Clark et al., 2003). Those research findings were become motivation to conduct this study. CR found effective no matter what gender, educational or cultural background, race and other domains of diversity (Zhang \& Stahl, 2011).

Those studies provided empirical evidence that collaborative reasoning would promote the critical thinking of the student, but none of them had mentioned CR on establish a moral comprehension. This paper aimed to fill that gap and prove that collaborative learning will promote the moral comprehension of students. The primary purpose of the CR paradigm in this study was to teach analytical reasoning skills that help learners not only how to developing morality but for reasons and understand why their moral comprehension is correct.

\section{METHODS}

The population in this study were students of tenth grade of State High School 1 Gegesik (312 students). The sample in this study were 40 students, 20 students in the experimental group and 20 students in the control group.

The research method used is a quasi-experimental research method in a quasiexperimental research method that has a control group but does not adequately function to control external variables that affect the implementation of the experiment.

The research design used is Non-Equivalent Control Group Design. This design is almost the same as the pre-test and post-test control group design, only in this design, the experimental group and the control group were not randomly selected, then given the pre-test 
and post-test to determine the difference between the experimental group and the control group.

\begin{tabular}{|ll|}
\hline $\mathrm{O}_{1} \mathrm{X}_{\mathrm{O}_{2}}$ \\
$\mathrm{O}_{3}$ & $\mathrm{O}_{4}$ \\
\hline
\end{tabular}

Figure 1. Quasi-experimental Design (Sugiyono, 2000).

Information:

$\mathrm{O} 1=$ Pre-test in the experimental class.

$\mathrm{O} 3=$ Pre-test in the control class.

$\mathrm{X}=$ Treatment with Role Playing Technique for the experimental class.

$\mathrm{O} 2=$ Post-test in the experimental class.

$\mathrm{O} 4=$ Post-test in the control class.

Moral comprehension instruments are made by referring to operational definitions of variables - moral comprehension instruments designed in the form of stories that contain stories of ethical dilemmas. Also, researchers will also conduct observations and interviews to support the presentation of the results of this study.

Alpha Cronbach's internal consistency in DIT is above 0.70. In this study, researchers used Rest's Defining Issues Test (DIT) to measure moral comprehension for juvenile delinquency (Rest, 1973). DIT is an objective multiple choice test, compiled based on the moral development theory of Kohlberg. There are currently two versions, namely DIT-1 and DIT-2. In this study, short DIT-1 (Short Form) was used. DIT-1 consists of 3 stories or social dilemmas concerning morals, each accompanied by 12 statements. Each of these statements reflects a particular stage of moral development or certain types of moral comprehension. For each subject, the comment must choose one of the five considerations that are available, namely: very important, vital, somewhat important, less important, and not significant. Next phase is determining the order (ranking), which statement according to the subject is the first most important statement, the second most important, the third most important and the fourth most important. Moral comprehension in this study was shown through the $\mathrm{P}$ value of the DIT. P value indicates the principle of morality, namely the ability of a person to be able to decide social problems related to morality that he faces by considering the moral tenets possessed.

The research data analysis procedure is divided into five phases: (1) data verification; (2) data scoring; (3) grouping and interpretation of instrument data; (4) preparation of group guidance programs with collaborative reasoning technique to develop students 'moral comprehension: and (5) data analysis to determine the effectiveness of using collaborative reasoning technique to develop students' moral comprehension.

\section{RESULTS AND DISCUSSION}

Research data were obtained from the calculation of scores DIT-1 test. This study aims to examine the level or moral stage of students using story of material moral dilemmas. Based on the data processing obtained from 312 students can be described the condition of moral comprehension ability which refers to the explanation of the stages of moral reasoning as can be seen in the Table 1 .

These results indicate that students of tenth grade have moral comprehension in stage 4 come to 66 students $(21.15 \%), 58$ students $(18.59 \%)$ who are in stage 3, 54 students $(17.31 \%)$ in stage 2,49 students $(15.71 \%)$ were in stage 5B, 43 students $(13.78 \%)$ were in stage 5A, and 42 students $(13.46 \%)$ in stage 6. 
The Table 1 shows that the level of moral comprehension of students in tenth grade of State High School 1 Gegesik which is the subject of the research are as follows; a) The preconventional level is shown in stages 1 and 2. Phase 1 is not used in this study, because according to Kohlberg stage 1 is owned by early childhood. Step 2 is called the relativistinstrumental orientation. b) The conventional level is shown in stages 3 and 4 . Phase 3 is called the harmony orientation stage or the orientation of good boy-nice girl, while step 4 is called the public order orientation. c) The post-conventional or autonomous level is shown in stages $5 \mathrm{~A}, 5 \mathrm{~B}$ as the orientation stage and stage 6 as the stage of universal ethical principles.

The implementation of collaborative reasoning techniques in form of guidance services in this study aims to develop the moral comprehension of tenth grade students of state State High School 1 Gegesik Academic year of 2017-2018. The results of data analysis indicate an improvement in the moral comprehension of students using collaborative reasoning techniques. Increasing the moral reasoning of students can be seen from the results of observations and the provision of guidance with collaborative reasoning techniques in solving of moral dilemma stories.

The improvement of students' moral reasoning based on the results of observations signed by the improvement of the response and activity of students at each service session. The first session and the second session, the students still passive and shy, and a few students who willing to speak up. The third and fourth session, some students have begun to dare to express their opinions and start participating if given the opportunity to speak as their group representatives. The fifth session and the sixth session, students began actively in arguing in their small groups and did not hesitate in their opinions.

The collaborative reasoning technique will be stated effective if there are significant differences between the pretest and posttest, and changed in moral comprehension scores. Data on the moral comprehension of students was obtained through the DIT-1 instrument given at the end of treatment in both classes of students (the experimental class and control class). After the students' moral reasoning data was collected, then analiyzed and grouped.

\begin{tabular}{ccc}
\hline Stages & Total $(\mathbf{f})$ & Percentage $(\boldsymbol{\%})$ \\
\hline Stage 2 & 54 & 17,31 \\
Stage 3 & 58 & 18,59 \\
Stage 4 & 66 & 21.15 \\
Stage 5a & 43 & 13.78 \\
Stage 5b & 49 & 15.71 \\
Stage 6 & 42 & 13,46 \\
\hline total & 312 & 100 \\
\hline
\end{tabular}

Table 1. Students Moral Comprehension

In addition to some of the above statistical tests, it is also necessary to test to see the moral comprehension of the experimental group students after being given intervention. It aims to find out whether there is a significant difference between the pre-test and posttest data. Results are presented in Table 2.

\begin{tabular}{cc}
\hline $\mathbf{Z}$ & $\mathbf{p}$ \\
\hline-0.650 & 0.516 \\
\hline
\end{tabular}

Table 2. Wilcoxon Signed Ranks Test

The Table 2 shows that there are significant differences between the two groups. So it can be concluded, guidance with collaborative reasoning techniques is effective in developing students' moral comprehension. In more detail the improvement of students' moral 
comprehension is also presented based on the stages of moral knowledge which can be seen in the following table:

\begin{tabular}{ccccc}
\hline Stage & $\begin{array}{c}\text { The number of } \\
\text { students } \\
\text { (pre-test) }\end{array}$ & Percentage (\%) & $\begin{array}{c}\text { The number of } \\
\text { students (post- } \\
\text { test) }\end{array}$ & Percentage (\%) \\
\hline 2 & 3 & $15 \%$ & 1 & $5 \%$ \\
3 & 5 & $25 \%$ & 4 & $20 \%$ \\
4 & 6 & $30 \%$ & 5 & $25 \%$ \\
$5 \mathrm{~A}$ & 3 & $15 \%$ & 5 & $25 \%$ \\
$5 \mathrm{~B}$ & 2 & $10 \%$ & 3 & $15 \%$ \\
6 & 1 & $5 \%$ & 2 & $10 \%$ \\
\hline
\end{tabular}

Table 3. The difference in Average Score based on Moral Comprehension Stages

The Table 3 shows changes in students' moral comprehension before and after being given a collaborative reasoning technique. The initial condition of students' moral reasoning in stage 4 as six students or by $30 \%$, decreasing to 5 students or by $25 \%$. The moral reasoning of students at the time before the intervention was a little in stages $5 \mathrm{~A}, 5 \mathrm{~B}$, and 6 . However, after the intervention was increased in step $5 \mathrm{~A}$, initially three students or by $15 \%$ increased to 5 students or by $25 \%$. Whereas in stage $5 \mathrm{~B}$ only two students or $10 \%$ increased to 3 students or $15 \%$. In the 6th stage only one student or $5 \%$ to 2 students or $10 \%$. From these results, the success criteria have been achieved because more than $50 \%$ of students are in stages 4,5 , and 6.

The impact of collaborative technique on increasing moral comprehension had proved by this research. This finding accordance to research finding on Enhancing Arthur Andersen business ethics vignettes (Peek, Peek, \& Horras, 1994), this research had not attempt to measure whether the individuals' moral levels changed, but whether the group discussions stimulated any changes in the students attitudes toward the particular ethical dilemma they viewed. Another research state that interacting groups reason at a significantly improve the moral reasoning (Nichols \& Day, 1982).

The importance of take a meaningful relationship to enable the growth had been stated (Moore \& Neto, 2018). The meaningful relationship will open any possibilities of growth and values that had transferred to the member of group. Furthermore, in certain circumstances an indirect communication based on meaningful relationship can be an important factor on individual growth. If a meaningful relationship has established then any purpose of the service is possible to achieve.

Eventhough this study provided an empirical evidence of $\mathrm{CR}$ effectiveness on improving moral comprehension, this study has limitation. Therefore, further investigation is still needed to find whether any other factors that able to intervene or mediate the improvement of moral comprehension.

Furthermore, guidance and counseling teacher or school counselor should provide collaborative learning on their guidance and counseling program list. This program should have supported by the school stakeholder (the headmaster, teacher and staff) due to provide a good service for the students (Subandi, 2015). Provision of material on moral dilemma stories to improve students' moral comprehension should often apply, therefore, students are accustomed to making the right decisions in every problem they face. The next study can develop other intervention technique to improve moral comprehension. The observations and other practices of moral awareness should more often applied at schools, therefore, students can better understand what is right and well behave in daily life in school, home environment, and in the publicly. 


\section{CONCLUSIONS}

Based on the results of the study, the categorization of moral comprehension shows that the majority of students in tenth grade State High School 1 Gegesik in this study are at the level of post-conventional morality with a percentage of $42.95 \%$. The philosophy of moral comprehension in tenth grade of State High School 1 Gegesik, in general, is in stage 4. Formulation of guidance and counseling programs with collaborative reasoning technique focused on developing students' moral comprehension at each stage and level of moral comprehension. Based on the results of the effectiveness test of Collaborative Reasoning Technique to Develop Moral comprehension for tenth grade Students of State High School 1 Gegesik proved effective.

From the results of the research, discussion, and conclusions that have been described previously, the researchers propose suggestions as follows; provision of material on moral dilemma stories, develop other intervention technique, observations and other practices of moral awareness should more often applied at schools.

\section{ACKNOWLEDGEMENTS}

The authors present their sincere appreciation goes to the head of guidance and counseling department Universitas Pendidikan Indonesia and to the thesis examiners for their advice, supervision and crucial improvement of the content of this manuscript. The authors appreciation also goes to the principal of State High School 1 Gegesik academic year of 2016/2017 for allowing the authors to conduct the research there.

\section{AUTHOR CONTRIBUTIONS STATEMENTS}

LW arranged the research proposal then discussed it with MS and THD. The research started with a detailed investigation of the theories and the problems. The data were collected by LW. After all, LW arranged the procedures of counseling intervention, giving treatment to the samples and wrote the report of the research. MS evaluated every data were collected by LW. THD evaluated and rechecked data of the investigation. LW wrote many important advice and supervision from MS and THD, then made revision based on their suggestion.

\section{REFERENCES}

Bonk, C. J., \& Dennen, V. (2007). Frameworks for design and instruction. Handbook of Distance Education, 2, 233-246. Retrieved from Google Scholar

Clark, A.-M., Anderson, R. C., Kuo, L., Kim, I.-H., Archodidou, A., \& Nguyen-Jahiel, K. (2003). Collaborative Reasoning: Expanding Ways for Children to Talk and Think in School. Educational Psychology Review, 15(2), 181-198. https://doi.org/10.1023/A:1023429215151

Desmita, D. (2009). Psikologi Perkembangan Peserta Didik. Remaja Rosdakarya. Retrieved from Google Scholar

Drchova, S. V., Hallstrom, J. O., Hollingsworth, J. E., Krone, J., \& Sitaraman, M. (2013). Teaching and Assessment of Mathematical Reasoning Principles Using a Concept Inventory, 21. Retrieved from Google Scholar

Duska, R., \& Whelan, M. (1975). Moral Development: A Guide to Piaget and Kohlberg. Retrieved from Google Scholar

Indonesia, K. K. R., \& Pencegahan, D. J. (2017). Laporan Perkembangan HIV-AIDS \& Penyakit Infeksi Menular Seksual (PIMS) Triwulan I Tahun 2017. Jakarta: Kemenkes $R I$. Retrieved from Google Scholar 
Ma'mun, N. (2012). Implementasi Pendidikan Karakter Pada Anak Usia Dini: Studi Kasus di TKA Al-Mukhlisin Cibodas Lembang (PhD Thesis). Universitas Pendidikan Indonesia. Retrieved from http://repository.upi.edu/9015/

Mariani, A., \& Bachtiar, I. (2011). Keterpaparan Materi Pornografi Dan Perilaku Seksual Siswa Sekolah Menengah Pertama Negeri. Hubs-Asia, 10(1). Retrieved from http://hubsasia.ui.ac.id/old/index.php/hubsasia/article/view/665

Moore, J., \& Neto, R. do C. A. (2018). Model of Teacher Moral Development. Revista @ mbienteeducação, 11(1), 11-28. https://doi.org/10.26843/ae19828632v11n12018p11a28

Mujahidah. (2009). Perilaku Menyontek Laki-laki dan Perempuan: Studi Meta Analisis. Jurnal Psikologi, 2(2), 177-199. Retrieved from http://digilib.uin-suka.ac.id/8860

Mulyani, E., Marliani, S. N., Sulistyorini, D., Lestari, S., Pinuri, W., Antasari, E., Azhim, Q. N. (2017). Survei Penyalahgunaan dan Peredaran Gelap Narkoba Pada Kelompok Pelajar dan Mahasiswa di 18 Provinsi Tahun 201. Jakarta: Badan Narkotika Nasional Bekerjasama dengan Pusat Penelitian Kesehatan Universitas Indonesia. Retrieved from Google Scholar

Nichols, M. L., \& Day, V. E. (1982). A Comparison of Moral Reasoning of Groups and Individuals on the "Defining Issues Test." Academy of Management Journal, 25(1), 201-208. https://doi.org/10.5465/256035

Peek, L. E., Peek, G. S., \& Horras, M. (1994). Enhancing Arthur Andersen business ethics vignettes: Group discussions using cooperative/collaborative learning techniques. Journal of Business Ethics, 13(3), 189-196. https://doi.org/10.1007/BF02074818

Rest, J. R. (1973). The hierarchical nature of moral judgment: A study of patterns of comprehension and preference of moral stages1. Journal of Personality, 41(1), 86-109. https://doi.org/10.1111/j.1467-6494.1973.tb00662.x

Reznitskaya, A., Kuo, L., Clark, A., Miller, B., Jadallah, M., Anderson, R. C., \& Nguyen-Jahiel, K. (2009). Collaborative reasoning: a dialogic approach to group discussions. Cambridge Journal of Education, 39(1), 29-48. https://doi.org/10.1080/03057640802701952

Santrock, J. W. (2014). Adolescence (15th ed.). New York: Mc. Graw Hiil Companies. Retrieved from Google Scholar

Subandi, S. (2015). Manajemen Mutu Layanan Konseling: Studi Kasus Layanan Konseling di MAN 1 Kota Metro. Al-Idarah: Jurnal Kependidikan Islam, 5(2). http://dx.doi.org/10.24042/alidarah.v5i2.761

Sugiyono, S. (2000). Metodologi Penelitian Pendidikan. Bandung: CV Alfabeta. Retrieved from Google Scholar

Young, M. K. (2014). Discussing the Big Quesions: Using Collaborative Reasoning in Literature Sudy (PhD Thesis). Retrieved from https://oaktrust.library.tamu.edu/handle/1969.1/154540

Zhang, J., \& Stahl, K. A. D. (2011). Collaborative Reasoning: Language-Rich Discussions for English Learners. The Reading Teacher, 65(4), 257-260. https://doi.org/10.1002/TRTR.01040 
Copyright Holder :

(c) Wahyuningsih, L., Solehuddin, M., \& Dahlan, T. H. (2019)

First Publication Right :

(c) Islamic Guidance and Counseling Journal

This article is under:

(ㄷ)(1) (2) 